\title{
ИСТОРИЯ
}

УДК 920.253

DOI: $10.21779 / 2542-0313-2018-33-4-6-18$

\section{О.Н. Болдырева}

\section{Роль калмыков в российско-китайских отношениях XVIII в.: историография}

Калмыцкий государственный университет им. Б.Б. Городовикова; Россия, Республика Калмыкия, 358000, г. Элиста, ул. Пушкина, 11; Olya.boldyreva2013@yandex.ru

Актуальность статьи определяется необходимостью предстоящего исследования роли Калмыцкого ханства в восточной политике России, в особенности в XVIII в., когда ханство находилось на вершине собственного развития. Это принципиально не только для истории калмыцкого народа, но и для исследования и освещения роли народов, которые входили в состав России, в ее внешнеполитической работе в тот либо другой период.

При анализе роли Калмыцкого ханства в политике в XVIII в. можно сравнить его отношения как в общем с Российской империей и регионом Центральной Азии, так и с некоторыми государствами, к примеру с Китаем. Известно, что степные народы, в том числе и калмыки, сыграли немаловажную роль в истории Центрально-Азиатского региона.

В данном плане исследование отношений Калмыцкого ханства с Цинской Китайской империей в XVIII в. представляется принципиальным. Во-первых, исследование истории отношений Калмыцкого ханства с обозначенным государством дает возможность констатировать его самостоятельность. Это значит, что Калмыкия могла иметь дипломатические отношения с государствами Центральной Азии.

Во-вторых, при анализе роли и места Калмыцкого ханства в восточной политике Российского государства нужно учесть отношение России к Китаю в обозначенный период, а также трудности в отношениях указанных ранее государств друг к другу и к Российской империи. Рассмотрение историографии заявленной в проблемы занимает важное место при изучении роли Калмыцкого ханства в восточной политике России и дает право утверждать, что Калмыцкое ханство играло немаловажную роль в политике, несмотря на протекторат России.

Ключевые слова: Калмыцкое ханство, Цинский Китай, историография, отношения, периоды, Россия, откочевка калмыков в Китай.

Историографию российско-китайских отношений XVIII в. условно можно поделить на три периода: дореволюционный, советский и современный. Если ознакомиться с историографией Калмыкии, несложно увидеть два обстоятельства: 1) дореволюционная историческая литература о калмыках имеет, за редчайшим исключением, этнографический характер; 2) советская же - обществен- 
но-финансовый, обществоведческий уклон. Потому в обеих историографиях меньше внимания уделялось связям калмыков со странами и народами за границей России [7, с. 6].

История калмыцко(ойратско)-китайских отношений включает в себя ряд веков, но в исторической литературе XVIII в. (а именно с этого времени начинается российская историография о калмыках) она освещена недостаточно. Интерес историков привлекли преимущественно редкие запоминающиеся моменты калмыцко-китайских отношений, подобные двум официальным приездам послов Китая на берега Нижней Волги, а также уход части калмыков в Синьцзян в 1771 г. [7, с. 6]

Но всеохватывающей картины отношений Калмыцкого ханства и Цинской империи в XVII-XVIII вв. сформировано не было. По нашему мнению, сложившееся положение объясняется не только отсутствием размеренных дипломатических или торговых взаимосвязей между Калмыкией и Китаем, но и тривиальной зависимостью внешнеполитических связей Калмыцкого ханства от России [7, с. 6]. При этом следует отметить, что процесс подчинения калмыцкой знати указаниям российского правительства шел равномерно и завершился лишь с ликвидацией Калмыцкого ханства как особенного государственного образования.

Статский советник, член-корреспондент Императорской академии наук по отделу Восточных литератур и древностей С.В. Липовцев занимался изучением и переводом источников на китайском языке, в частности он исследовал сочинения китайского князя Цишия [28, с. 254-269].

В начале XIX в. известный ориенталист и китаист Н.Я. Бичурин (Иакинф) утверждал, что в XVIII в. калмыки, после того как обустроились в России, не только сохранили отношения с Джунгарией, но и поддерживали связь с Китайской империей и Тибетом [Бичурин]. Являясь для своего времени непревзойденным знатоком официальной китайской историографии, историю ойратов и калмыков Н.Я. Бичурин излагал главным образом с ее позиций. Потому сначала он показал позицию китайской дипломатии в отношениях с Джунгарским и Калмыцким ханствами. Близким к его позиции было мнение многих авторов XIX в. - Бюлера Ф.А., Костенкова К.И., Позднеева А.М. и других, которые утверждали, что кабинет министров России, фактически не вмешиваясь во внутреннее управление ханством, пробовал держать под строгим контролем его внешнюю политику [7, с. 7].

Например, Ф.А. Бюлер оценивал характер отношений царского правительства с правителями калмыков как «отношения больше дипломатические, чем властелинские» [11]. Генерал-майор К.И. Костенков, действительный статский советник, член Императорского Русского географического общества (ИРГО), с конца 50-х до начала 70-х гг. ХІХ в. главный попечитель калмыцкого народа, внес значимый вклад в исследование истории попечительствующего народа [7, c. 7]. В 1870 г. он издал в Санкт-Петербурге свой труд «Исторические и статистические сведения о калмыках, кочующих в Астраханской губернии»», составленный на базе архивных материалов Управления калмыцким народом и Полного собрания законов [7, с. 7]. Согласно его убеждению, калмыцкие ханы начали 
осуществлять политическую деятельность, направленную на увеличение количества зависимого от них населения за счет переселенцев из Джунгарии [17].

В числе изучаемых авторами XIX в. вопросов особое место занимала история отношений Калмыцкого ханства с народами и странами Центральной Азии. Бесспорной заслугой авторов этого периода стало накопление нового исторического материала и введение его в научный оборот, что создавало основу для следующих более глубоких и масштабных исследовательских работ [7, с. 8].

История советского калмыковедения начинается с работ профессора Н.Н. Пальмова. В «Очерках по истории калмыцкого народа» Н.Н. Пальмов выдвинул идею о том, что, уже являясь российскими подданными, калмыки считали, что продолжают находиться в составе монгольского сообщества под управлением ламаистского центра в Тибете [29]. В «Этюдах по истории приволжских калмыков XVII-XVIII века» [30] он уделил существенное внимание внешнеполитическим акциям Калмыцкого ханства [7, с. 8].

В частности, Н.Н. Пальмов осветил историю китайских посольств в 1714 и 1731 гг. Он, как и некоторые предшествующие авторы, склонен был думать, что интерес цинского кабинета министров к калмыкам был определен политическими планами. Китай готовился к решительной схватке с Джунгарским ханством и в связи с этим искал для себя вероятных единомышленников [7, с. 9]. Но, как верно отмечал Н.Н. Пальмов, Цины скоро удостоверились, что калмыцкие правители не полностью свободны в собственных внешнеполитических отношениях, так как они контролируются российским правительством. Касательно Джунгарии Н.Н. Пальмов подчеркивал, что союзнические отношения с ней могли бы дать некую политическую выгоду Калмыцкому ханству, но уже Аюка осознавал неизбежность ее падения под натиском Китая [7, с. 9].

Приезд в Россию двух китайских посольств в начале 30-х гг. XVIII в. анализировала историк К.Ш. Хафизова [33]. Она предполагает, что целью этих посольств было проведение политики «отрезания правой руки», другими словами - попытки склонить единомышленников на сторону Китая методом изоляции врагов с запада. Исследованием российско-китайских отношений также занимается И.Т. Мороз. Преимущественно ее интересуют китайские посольства в России [25]. Она считает, что целью прибытия Тулишеня к калмыцкому хану Аюке в 1714 г. был не Арабжюр, а поиск сведений о калмыцком нойоне - одна из задач китайского посольства в Москве в 1731 г. [7, с. 10].

В постсоветский период исследованием калмыцко-джунгарских отношений занимались такие исследователи, как М.М. Батмаев, В.П. Санчиров, А.Г. Митиров, В.И. Колесник, А.В. Цюрюмов. В работе М.М. Батмаева тщательно исследована деятельность российского кабинета министров во время подготовки и откочевки в 1771 г. М.М. Батмаев считает колонизацию приволжских степей и наступление на автономию ханства главными факторами откочевки [7, с. 10]. Он сделал вывод, что откочевка 1771 г. была связана со спонтанно развивающимися событиями, но не была итогом какого-то плана, продуманного заблаговременно и планомерно реализованного [3].

А.В. Цюрюмов впервые исследовал роль и значение Калмыцкого ханства во внешнеполитической концепции Российской империи [37]. Он подчеркнул,

8 Вестник Дагестанского государственного университета.

Серия 2. Гуманитарные науки. 2018. Том. 33. Вып. 4 
что причинами откочевки калмыков являются разногласия, появившиеся в калмыцко-российских отношениях. Они развивались в течение первой - третьей четверти XVIII в. Однако решение об уходе было реализовано не сразу в связи с тем, что в степях Западной Монголии было Джунгарское ханство. Истинные очертания откочевка приобрела лишь после гибели Джунгарского ханства в конце 1750-х гг. [7, с. 11].

В.П. Санчиров изучил политическую деятельность Цинского Китая в 70-е гг. XVIII в. во взаимоотношениях с волжскими калмыками [7, с. 11]. Для автора откочевка 1771 г. представляется авантюрным делом, задуманным ханом Убаши и его приспешниками для решения собственных эгоистичных целей [32, с. 6077].

В 1760-х гг. Россия начала преобразование административноуправленческой системы Калмыцкого ханства, что в результате означало наступление на его автономность. Одновременно пало Джунгарское государство [7, с. 11]. Возникла возможность возобновления независимой государственности приволжских калмыков на его территории. Данные условия стали главным фактором событий 1771 г. [31].

В.А. Моисеев и Б.П. Гуревич обосновали беспочвенность притязаний китайских ученых на Джунгарию как часть Цинской империи, и то, что Джунгария владела независимостью в межгосударственных отношениях в Центральной Азии [21, с. 100-125]. В.А. Моисеев и О.А. Глушкова анализировали военностратегические цели, поставленные перед цинским посольством в Калмыцком ханстве 1731 г. [23, с. 96-103; 14, с. 183]. Проблема разгрома Джунгарского ханства Цинской империей всесторонне изучалась в отечественной историографии: исследовались предпосылки агрессии китайцев в Центральной Азии, а также их методы и стратегия (В.А. Моисеев, Б.П. Гуревич, Л.И. Думан, Д.В. Дубровская, А. Ходжаев, К.Ш. Хафизова) [24].

Авторы советской и современной историографии И.А. Чернышев [40], Ш.Б. Чимитдоржиев [41, с. 62-66], М.М. Батмаев [3], А.Б. Насунов [26, с. 8889], А.В. Цюрюмов [36], И.В. Вишнякова [12; 13] обращались к одному из более разработанных вопросов - откочевке калмыков в Китайскую империю в 1771 г. Более обширно данная тема была раскрыта в работах В.И. Колесника и Е.В. Дорджиевой $[15 ; 16]$.

В 2007 г. И.А. Ноздрина в своей работе рассматривала Калмыцкое ханство как элемент системы межгосударственных связей, соответствующих Центральной Азии в XVIII в. [27]. Ею рассмотрены законодательная стратегия российского правительства в отношении принимаемых в российское подданство джунгар и их роль в российско-китайских отношениях в 50-60-е гг. XVIII в. Акцентируется внимание на политике российского кабинета министров, которая проводилась для возврата ушедших в 1771 г. с Волги калмыков [7, с. 14].

В 2008 г. издал свою книгу Е.Л. Беспрозванных [5], где изложил историю политических отношений между Калмыцким ханством и Цинской империей. Повествование начинается с периода правления хана Аюки, на время которого приходится расцвет ханства, а заканчивается временем его устранения [7, с. 14]. 
По его словам, «калмыцкая дипломатия не была чем-то застывшим. На протяжении XVIII в. она меняла свои приемы и методы, постепенно приобретая форму тайной дипломатии. Это было связано с наличием нескольких внутренних и внешних факторов, влиявших на традиционную дипломатию» [5, с. 29].

Астраханский историк А.А. Курапов изучал политику России по отношению к Калмыцкому ханству в контексте буддийской общины калмыков [19]. Он подчеркивает, что с 1724 г. правительство России для решения внутриполитических вопросов в Калмыцком ханстве обращалось к верховному ламе ханства Шакур-ламе [7, с. 15]. Потом роль буддийской общины уменьшилась, а после устранения ханства в 1771 г. правительство России всецело захватило управления калмыцкой общиной в свои руки [7, с. 15].

Вследствие того, что автора статьи интересуют калмыцко-китайские отношения, заграничная историография представлена китайскими авторами, исследовавшими историю ойратов.

В труде автора XIX в. Хэ Цютао «Шофан бэйчен 朔方备乘 (Описание северной границы)» исторические главы повествуют о более ранних народах и племенах, которые обитали на приграничной территории и в Сибири [7, с. 16]. Исследователь утверждал, что русские являются потомками племени усуней, которые откочевали из района, находящегося меду Тибетом и Восточным Туркестаном, в Сибирь [34].

В 1992 г. в Институте истории Синьцзянской академии общественных наук вышла монография китайского ученого монгольского происхождения АлтанаОчира «Вэйлатэ мэнгу цзяньши 卫拉特蒙古简史» (Краткая история ойратмонголов), в которой автор делится представлением о ликвидации Джунгарского ханства, об отношении джунгарского хана Цеван-Рабдана к Цинской империи, его отношениях с российским императором Петром Первым, о союзе джунгарского хана Даваци с нойном Амурсаной в 50-х гг. XVIII в. и иными вопросами [2].

Исследователи Ма Даджен и Ма Рухан изучали период откочевки калмыцкого народа в Китайскую империю в 1771 г., предпосылки и результаты этого события [20]. Кроме того, в Институте России, Восточной Европы и Центральной Азии Академии общественных наук КНР историк Чжао Чанцин изучил историю пяти стран Центральной Азии, а также калмыцко-китайские отношения. Он подчеркивает, что к окончанию 50 - началу 60-х гг. XVIII в. цинская экспансия в Центральной Азии достигла своего пика [7, с. 16]. Сразу после образования синьцзянского наместничества правительство Китая столкнулось с чередой внутри- и внешнеполитических проблем, которые препятствовали распространению воздействия в Центральной Азии [18].

Изучая историографию данной проблемы, автор делает заключение, что калмыки играли немаловажную роль в российско-китайских отношениях в XVIII в., невзирая на протекторат России. На это указывает большое количество работ отечественной и китайской историографии, которые были посвящены исследованию этой темы. При анализе роли Калмыцкого ханства в политике XVIII в. можно сравнить его отношения как в общем с Россией и регионом Центральной Азии, так и с некоторыми государствами, к примеру с Китайской им- 
перией. Известно, что степные народы, в том числе и калмыки, сыграли немаловажную роль в истории Центрально-Азиатского региона. В данном плане исследование отношений Калмыцкого ханства с Цинским Китаем в XVIII веке представляется принципиальным. Во-первых, исследование истории отношений Калмыцкого ханства с обозначенным государством дает возможность констатировать самостоятельность ханства, невзирая на протекторат России. Это значит, что Калмыкия могла иметь дипломатические отношения с государствами Центральной Азии. Во-вторых, при анализе роли и места Калмыцкого ханства в восточной политике России нужно учесть отношение Российского государства к Китаю в обозначенный период, а также трудности в отношениях указанных ранее государств друг к другу и к России.

\section{Литература}

1. Khodarkovsky M. Where Two World Met: The Russian State and the Kalmyk Nomads, 1600-1771. - Ithaca, N.Y.: Cornell University Press, 1992.

2. Алтан-Очир. Вэйлатэ мэнгу цзяньши 卫拉特蒙古简史 (Краткая история ойрат-монголов): монография. - Синьцзян, 1992. - Т. 1.

3. Батмаев M.M. Калмыки в XVII-XVIII веках: события, люди, быт; в 2 кн. - Элиста: Калмкнигоиздат, 1993.

4. Батмаев М.М. Социально-политический строй и хозяйство калмыков в XVII-XVIII вв. - Элиста: АПП «Джангар», 2002.

5. Беспрозванных E.Л. Калмыцко-китайские отношения в XVIII веке. Волгоград: Изд-во ВолГУ, 2008.

6. Бичурин Н.Я. Историческое обозрение ойратов, или калмыков, с XV столетия до настоящего времени. - 2-е изд. - Элиста: Калм. книжное изд-во, 1991.

7. Болдырева О.Н. Калмыцкое ханство в восточной политике России в XVIII в.: дис. ... к. ист. н.: 07.00.02. - Элиста, 2018. - 182 с.

8. Болдырева О.Н. К вопросу о заключении Цинским Китаем военного союза с калмыками в середине XVIII в. // Вестник Калмыцкого государственного университета. - 2017. - № 3 (35). - С. 33-39.

9. Болдырева О.Н. О положении калмыков в Цинской империи в конце XVIII в. // Современные аспекты общественно-политического развития России и стран мира. VI Международная научно-практическая конференция / гл. ред. А.А. Киселев. - Краснодар: Рекламное агентство «Пресс-Имидж», 2013. - С. $3-$ 7.

10. Болдырева О.Н. Взгляд Н.Н. Пальмова на взаимоотношения Калмыцкого ханства с Джунгарским ханством и Китаем в начале XVIII в. // Народы Евразии. История, культура и проблемы взаимодействия: материалы II Международной научно-практической конференции / гл. ред. В.А. Дорошина. - Пенза: ООО Научно-издательский центр «Социосфера», 2012. - С. 204-205.

11. Бюлер Ф.А. Кочующие и оседло-живущие в Астраханской губернии инородцы. Их история и настоящий быт. T. XLVII. Отд. II. - СПб.: Отечественные записки, 1846. 
12. Вишнякова И.В. К вопросу об участии казахов Младшего и Среднего жузов в преследовании волжских калмыков во время их бегства в Джунгарию в 1771 г. // Актуальные вопросы истории Сибири. Третьи научные чтения памяти проф. А.П. Бородавкина: материалы Всероссийской конференции / под ред. В.А. Скубневского, К.А. Пожарской. - Барнаул: Алтайский государственный университет, 2002. - С. 407-410.

13. Вишнякова И.В. К вопросу о бегстве волжских калмыков в Джунгарию в 1771 году // Востоковедные исследования на Алтае. Вып. II / гл. ред. Д.А. Глазунов. - Барнаул: Алтайский государственный университет, 2000. С. 45-54.

14. Глушкова О.А. Посольство Цинского Китая в России в 1730-1731 гг. // XII научная конференция «Общество и государство в Китае». Тезисы докладов. Ч. ІІ / гл. ред. А.И. Кобзев. - М.: Институт востоковедения РАН, 1988. C. 183.

15. Доржиева Е.В. Исход калмыков в Китай в 1771 г. - Ростов н/Д: Издво СКНЦ ВШ, 2002.

16. Колесник В.И. Последнее великое кочевье. - М.: Восточная литератуpa PAH, 2003.

17. Костенков К.И. Исторические и статистические сведения о калмыках, кочующих в Астраханской губернии. - СПб.: Мин-во государственных имуществ, 1870.

18. Краткий очерк пяти государств Центральной Азии / под ред. Чжао Чанцина. - Институт России, Восточной Европы и Центральной Азии Академии общественных наук КНР, март, 1998.

19. Kурапов A.A. Буддийское духовенство в социально-политической истории Калмыцкого ханства: XVII-XVIII вв.; дис. ... к. ист. н. - Элиста, 2004.

20. Ма Рухан, Ма Даджен. Вэйлатэ мэнгу шиган 卫拉特蒙古史纲 (Народ, оставшийся на чужбине). - Пекин: Гуанси шифань дасюэ чубаньшэ, 1997.

21. Международные отношения в Центральной Азии, XVII-XVIII вв.: документы и материалы / АН СССР, Ин-т востоковедения, Академия наук МНР, Ин-т востоковедения; сост. Б.П. Гуревич, В.А. Моисеев. - М.: Наука, 1989.

22. Моисеев B.A. Россия и Джунгарское ханство в XVIII веке. - Барнаул: Алтайский государственный университет, 1998.

23. Моисеев B.A. Дело Шопо-Лоузана (к истории посольств из Цинского Китая в Россию в 30-е гг. XVIII в.) // XIV научная конференция «Общество и государство в Китае». Тезисы и доклады. Ч. II / гл. ред. А.И. Кобзев. - М.: Институт востоковедения РАН, 1983. - С. 96-103.

24. Моисеев В.А., Хафизова К.Ш. Цинская империя и казахские ханства. Вторая половина XVIII - первая треть XIX в. Книги 1-2. - Алма-Ата: Гылым, 1989.

25. Мороз И.Т. О первом китайском посольстве в Москву (1729-1732 гг.) // Раздвигая горизонты науки. К 90-летию академика С.Л. Тихвинского / гл. ред. М.Л. Титаренко. - М.: Памятники исторической мысли, 2008. - С. 19-25.

26. Насунов А.Б. Роль Тибета в осуществлении откочевки основной массы калмыков в Джунгарию в 1771 г. // Цыбиковские чтения: 5-я Всесоюзная науч. 
конф.: Тез. докл. и сообщ. - Улан-Удэ: Бурят. ин-т обществ. наук, 1989. - С. 8889.

27. Ноздрина И.А. Калмыцкое ханство в системе международных отношений в Центральной Азии в XVIII веке. - Барнаул: Алтайский государственный университет, 2007.

28. О переходе торгоутов в Россию и обратном их удалении из России в Зюнгарию. Сочинение китайского князя Цишия, переведенное С.В. Липовцевым // Сибирский вестник. - 1820. - Ч. 2. - С. 214-235; Ч. 12. - С. 254-269.

29. Пальмов Н.Н. Очерки по истории калмыцкого народа за время его пребывания в пределах России. - Астрахань: Калмыцкое гос. изд-во, 1922.

30. Пальмов H.H. Этюды по истории приволжских калмыков XVIIXVIII вв. - Ч. 1-5. - Астрахань: Калмыцкое гос. изд-во, 1926-1932.

31. Санчиров В.П. История ойратов XV-XVII веков в трудах дореволюционных русских востоковедов // Калмыковедение: вопросы историографии и библиографии / гл. ред. Л.С. Бурчинова. - Элиста: Калм. НИИ истории, филологии и экономики, 1988. - С. 19-40.

32. Санчиров В.П. Приволжские калмыки в составе Цинской империи в конце XVIII века // Общественный строй и социально-политическое развитие дореволюционной Калмыкии / отв. ред. К.П. Шовунов. - Элиста: Калм. НИИ истории, филологии и этнографии, 1983. - С. 60-77.

33. Хафизова К.Ш. Китайская дипломатия в Центральной Азии (XIVXIX вв.): автореф. дис. ... д-ра ист. н.: 07.00.03 / Рос. академия наук. Ин-т Дальнего Востока. - М., 1995.

34. Хэ Цютао. Шофан бэйчен 朔方备乘 (Описание северной границы). Т. 1. - Пекин, 1881. - С. 102-103.

35. Цюрюмов A.B. Калмыцкое ханство в составе России: проблемы политических взаимоотношений. - Элиста: АОР «Джангар», 2006.

36. Цюрюмов A.B. О причинах откочевки калмыков в Китай в 1771 году // Россия, Сибирь и Центральная Азия: взаимодействие народов и культур: материалы III Международной научно-практической конференции / отв. ред. В.С. Бойко. - Барнаул: Лаб. «Россия и восток» БГПУ, 2001. - С. 10-15.

37. Цюрюмов A.B. Калмыцкое ханство в конце 60 - начале 70-х годов XVIII в.: итоги и перспективы развития // Проблемы современного калмыковедения / отв. ред. А.В. Бадмаев. - Элиста: Калмыцкий государственный университет им. Б.Б. Городовикова, 2001. - С. 143-150.

38. Цюрюмов А.В. Социально-экономическое состояние Калмыцкого ханства накануне откочевки во второй половине XVIII в. // Экономическая история России: проблемы, поиски, решения / отв. ред. М.М. Загорулько. - Волгоград: Волгоградский государственный университет, 2003. - С. 183-190.

39. Цюрюмов A.B. К вопросу об откочевке калмыков в Китай: социальноэкономические причины // Экономические проблемы в истории России и пути их решения. - СПб.: Нестор, 2003. - С. 10-11.

40. Чернышев И.А. О перекочевке волжских калмыков в Джунгарию в 1771 г. // XV научная конференция «Общество и государство в Китае». Тезисы 
докладов. Ч. ІІ / гл. ред. А.И. Кобзев. - М.: Институт востоковедения РАН, 1984. - C. $152-161$.

41. Чимитдоржиев Ш.Б. О перекочевках ойратов (калмыков) в XVIIXVIII вв. «Торгутский побег» 1771 г. // Исследования по истории и культуре Монголии / отв. ред. Ш.Б. Чимитдоржиев. - Новосибирск: Наука: Сиб. отд., 1989. - C. 62-66.

\section{References}

1. Khodarkovsky M. Where Two World Met: The Russian State and the Kalmyk Nomads, 1600-1771. - Ithaca, N.Y.: Cornell University Press, 1992.

2. Altan-Ochir Vehjlateh mehngu czyan'shi 卫拉特蒙古简史 (Kratkaya istoriya ojrat-mongolov) [Wailate Mengu Jian Shi (A short history of the Oirat-Mongols)]: monografiya. Sin'czyan, 1992. - T. 1.

3. Batmaev M.M. Kalmyki v XVII-XVIII vekah: Sobytiya, lyudi, byt. [Kalmyks in the XVII-XVIII centuries: Events, people, life]. V dvuh knigah. - Elista: Kalmknigoizdat, 1993 (In Russian)

4. Batmaev M.M. Social'no-politicheskij stroj i hozyajstvo kalmykov v XVIIXVIII vv. [The socio-political system and economy of the Kalmyks in the XVIIXVIII centuries]. - Elista: APP «Dzhangar», 2002 (In Russian)

5. Besprozvannyh E.L. Kalmycko-kitajskie otnosheniya v XVIII veke [KalmykChinese relations in the XVIII century]. - Volgograd: Izd-vo VolGU, 2008. (In Russian)

6. Bichurin N.Ya. Istoricheskoe obozrenie ojratov ili kalmykov s XV stoletiya do nastoyashchego vremeni [Historical review of Oirats or Kalmyks from the 15th century to the present]. - 2-e izd. - Elista: Kalm. kn. izd-vo, 1991. (In Russian)

7. Boldyreva O.N. Kalmyckoe hanstvo v vostochnoj politike Rossii v XVIII v. [Kalmyk khanate in the Eastern policy of Russia in the XVIII century]: dis. ... kand. ist. nauk. - Elista, 2018. - 182 s. (In Russian)

8. Boldyreva O.N. K voprosu o zaklyuchenii Cinskim Kitaem voennogo soyuza s kalmykami v seredine XVIII v. [On the issue of the conclusion by Ch'ing China of a military alliance with the Kalmyks in the middle of the 18th century.] // Vestnik Kalmyckogo gosudarstvennogo universiteta, - 2017. - № 3 (35). - S. 33-39. (In Russian)

9. Boldyreva O.N. O polozhenii kalmykov v Cinskoj imperii v konce XVIII v. [On the situation of the Kalmyks in the Ch'ing Empire at the end of the XVIII century.] In A.A. Kiselev Sovremennye aspekty obshchestvenno-politicheskogo razvitiya Rossii i stran mira. VI Mezhdunarodnaya nauchno-prakticheskaya konferenciya. Krasnodar: Reklamnoe agentstvo «Press-Imidzh», 2013. - S. 3-7. (In Russian)

10. Boldyreva O.N. Vzglyad N.N. Pal'mova na vzaimootnosheniya Kalmyckogo hanstva s Dzhungarskim hanstvom i Kitaem v nachale XVIII v. [Glance N.N. Palmova on the relationship of the Kalmyk Khanate with the Dzungar Khanate and China in the beginning of the XVIII century]. In V.A. Doroshina (Ed.), Narody Evrazii. Istoriya, kul'tura i problemy vzaimodejstviya: materialy II mezhdunarodnoj nauchno-prakticheskoj konferencii. - Penza: OOO Nauchno-izdatel'skij centr «Sociosfera». - 2012. - S. 204-205. (In Russian) (In Russian) 
11. Byuler F.A. Kochuyushchie i osedlo-zhivushchie v Astrahanskoj gubernii inorodcy. Ih istoriya i nastoyashchij byt [Traveling and settled-living in Astrakhan province are foreigners. Their history and real life]. T. XLVII. Otd. II. - SPb: Otechestvennye zapiski, 1846 (In Russian)

12. Vishnyakova I.V. K voprosu ob uchastii kazahov Mladshego i Srednego zhuzov v presledovanii volzhskih kalmykov vo vremya ih begstva v Dzhungariyu v $1771 \mathrm{~g}$. [On the question of the participation of Kazakhs of the Younger and Middle Zhuzes in the persecution of the Volga Kalmyks during their flight to Dzungaria in 1771]. In V.A. Skubnevskij, K.A. Pozharskaya (Ed.), Aktual'nye voprosy istorii Sibiri. Tret'i nauchnye chteniya pamyati prof. A.P. Borodavkina: materialy Vserossijskoj konferencii. - Barnaul: Altajskij gosudarstvennyj universitet, 2002. - S. 407-410.

13. Vishnyakova I.V. K voprosu o begstve volzhskih kalmykov v Dzhungariyu v 1771 godu [On the question of the flight of the Volga Kalmyks to Dzungaria in 1771]. In D.A. Glazunov (Ed.), Vostokovednye issledovaniya na Altae. Vyp. II. Barnaul: Altajskij gosudarstvennyj universitet, 2000. - S. 45-54. (In Russian)

14. Glushkova O.A. Posol'stvo cinskogo Kitaya v Rossii v 1730-1731 gg. [Embassy of the Qing China in Russia in 1730-1731]. In A.I. Kobzev (Ed.), XII nauchnaya konferenciya «Obshchestvo i gosudarstvo v Kitae». Tezisy dokladov. Ch. II. - M.: Institut vostokovedeniya RAN, 1988. - S. 183 (In Russian)

15. Dorzhieva E.V. Iskhod kalmykov v Kitaj v 1771 g. [Exodus of the Kalmyks to China in 1771]. - Rostov n/D: Izd-vo SKNC VSH, 2002. (In Russian)

16. Kolesnik V.I. Poslednee velikoe kochev'e [The last great nomad camp]. M.: Vostochnaya literatura RAN, 2003.

17. Kostenkov K.I. Istoricheskie i statisticheskie svedeniya o kalmykah, kochuyushchih v Astrahanskoj gubernii [Historical and statistical information about the Kalmyks, wandering in the Astrakhan province]. - SPb.: M-vo gos. imushchestv, 1870. (In Russian)

18. Kratkij ocherk pyati gosudarstv Central'noj Azii [A brief outline of the five states of Central Asia] / In Chzhao Chancina (Ed.), Institut Rossii, Vostochnoj Evropy i Central'noj Azii Akademii obshchestvennyh nauk KNR, 1998.

19. Kurapov A.A. Buddijskoe duhovenstvo $\mathrm{v}$ social'no-politicheskoj istorii Kalmyckogo hanstva: XVII-XVIII vv. [Buddhist clergy in the socio-political history of the Kalmyk Khanate: XVII-XVIII centuries]: dis. ... k. ist. n. - Elista, 2004. (In Russian)

20. Ma Ruhan, Ma Dadzhen Vehjlateh mehngu shigan 卫拉特蒙古史纲 (Narod, ostavshijsya na chuzhbine) [Vailate Mengue Shigan (The people who stayed in a foreign land)]. - Pekin: Guansi shifan' dasyueh chuban'sheh, 1997.

21. Mezhdunarodnye otnosheniya v Central'noj Azii, XVII-XVIII vv.: Dokumenty i materialy [International Relations in Central Asia, XVII-XVIII centuries: Documents and Materials] / In B.P. Gurevich, V.A. Moiseev (Ed.), AN SSSR, In-t vostokovedeniya, Akad. nauk MNR, In-t vostokovediy. - M.: Nauka, 1989 (In Russian) 
22. Moiseev V.A. Rossiya i Dzhungarskoe hanstvo v XVIII veke [Russia and the Dzungarian Khanate in the 18th Century]. - Barnaul: Altajskij gosudarstvennyj universitet, 1998. (In Russian)

23. Moiseev V.A. Delo Shopo-Louzana ( $\mathrm{K}$ istorii posol'stv iz cinskogo Kitaya $\mathrm{V}$ Rossiyu v 30-e gg. XVIII v.) [The case of Shopo-Lawan (On the history of embassies from Qing China to Russia in the 30s of the 18th century)] // In A.I. Kobzev (Ed.), Chetyrnadcataya nauchnaya konferenciya «Obshchestvo i gosudarstvo v Kitae». Tezisy i doklady. Ch. II. - M.: Institut vostokovedeniya RAN, 1983. - S. 96-103. (In Russian)

24. Moiseev V.A., Hafizova K.Sh. Cinskaya imperiya i kazahskie hanstva. Vtoraya polovina XVIII - pervaya tret' XIX vv. [The Qing Empire and the Kazakh Khanates. The second half of the XVIII - the first third of the XIX centuries] Knigi 12. - Alma-Ata: Gylym, 1989. (In Russian)

25. Moroz I.T. (2008). O pervom kitajskom posol'stve v Moskvu (17291732 gg.) [About the first Chinese embassy in Moscow (1729-1732 gg.)] / In M.L. Titarenko (Ed.), Razdvigaya gorizonty nauki. K 90-letiyu akademika S.L. Tihvinskogo. - M.: Pamyatniki istoricheskoj mysli. - S. 19-25 (In Russian)

26. Nasunov A.B. Rol' Tibeta v osushchestvlenii otkochevki osnovnoj massy kalmykov v Dzhungariyu v $1771 \mathrm{~g}$. [The role of Tibet in the implementation of the migration of the bulk of the Kalmyks to Dzungaria in 1771] // Cybikovskie chteniya: 5-ya Vsesoyuz. nauch. konf.: Tez. dokl. i soobshch. - Ulan-Udeh: Buryat. in-t obshchestv. nauk, 1989. - S. 88-89 (In Russian)

27. Nozdrina I.A. Kalmyckoe hanstvo v sisteme mezhdunarodnyh otnoshenij v Central'noj Azii v XVIII veke [Kalmyk Khanate in the system of international relations in Central Asia in the XVIII century]. - Barnaul: Altajskij gosudarstvennyj universitet, 2007. (In Russian)

28. O perekhode torgoutov v Rossiyu i obratnom ih udalenii iz Rossii v Zyungariyu [On the transition of merchants to Russia and their reverse removal from Russia to Zyungaria]. Sochinenie kitajskogo knyazya Cishiya, perevedennoe S.V. Lipovcevym // Sibirskij vestnik. 1820. Ch. 2. - S. 214-235; Ch. 12. - S. 254269.

29. Pal'mov N.N. Ocherki po istorii kalmyckogo naroda za vremya ego prebyvaniya $\mathrm{v}$ predelah Rossii [Essays on the history of the Kalmyk people during his stay in Russia]. Astrahan': Kalmyckoe gos. izd-vo, 1922. (In Russian)

30. Pal'mov N.N. Etyudy po istorii privolzhskih kalmykov XVII-XVIII vv. [Studies on the history of the Volga Kalmyks of the XVII-XVIII century]. Ch. 1-5. Astrahan': Kalmyckoe gos. izd-vo, 1926-1932. (In Russian)

31. Sanchirov V.P. Istoriya ojratov XV-XVII vekov $\mathrm{v}$ trudah dorevolyucionnyh russkih vostokovedov [History of Oirats of the XV-XVII centuries in the works of pre-revolutionary Russian orientalists]. In L.S. Burchinova (Ed.), Kalmykovedenie: voprosy istoriografii i bibliografii. - Elista: Kalm. NII istorii, filologii i ehkonomiki, 1988. - S. 19-40. (In Russian)

32. Sanchirov V.P. Privolzhskie kalmyki v sostave Cinskoj imperii v konce XVIII veka [Privolzhskiye Kalmyks as part of the Ch'ing Empire at the end of the XVIII century]. In K.P. SHovunov (Ed.), Obshchestvennyj stroj i social'no- 
politicheskoe razvitie dorevolyucionnoj Kalmykii. - Elista: Kalm. NII istorii, filologii i ehtnografii, 1983. - S. 60-77. (In Russian)

33. Hafizova K.Sh. Kitajskaya diplomatiya v Central'noj Azii (XIV-XIX vv.) [Chinese diplomacy in Central Asia (XIV-XIX centuries)]: avtoref. dis. ... d-ra ist. n.: 07.00.03 / Ros. akademiya nauk. In-t Dal'nego Vostoka. - Moskva, 1995. (In Russian)

34. Heh Cyutao. Shofan behjchen 朔方备乘 (Opisanie severnoj granicy) [Shofan beychen (Description of the northern border)]. T. 1. - Pekin, 1881. - S. 102-103.

35. Cyuryumov A.V. Kalmyckoe hanstvo v sostave Rossii: problemy politicheskih vzaimootnoshenij [kalmyk Khanate in Russia: the problems of political relations]. Elista: AOR «Dzhangar», 2006. (In Russian)

36. Cyuryumov A.V. O prichinah otkochevki kalmykov v Kitaj v 1771 godu [On the causes of the Kalmyks' migration to China in 1771]. In V.S. Bojko (Ed.), Rossiya, Sibir' i Central'naya Aziya: vzaimodejstvie narodov i kul'tur. Materialy III mezhdunarodnoj nauchno-prakticheskoj konferencii. - Barnaul: Lab. "Rossiya i vostok" BGPU, 2001. - S. 10-15. (In Russian)

37. Cyuryumov A.V. Kalmyckoe hanstvo v konce $60-\mathrm{h}$ - nachale 70 -h godov XVIII v.: itogi i perspektivy razvitiya [Kalmyk Khanate in the late 60 - early 70 -ies of the XVIII century: the results and prospects for development] // In A.V. Badmaev (Ed.), Problemy sovremennogo kalmykovedeniya. - Elista: Kalmyckij gosudarstvennyj universitet imeni B.B. Gorodovikova. - 2001. - S. 143-150. (In Russian)

38. Cyuryumov A.V. Social'no-ehkonomicheskoe sostoyanie Kalmyckogo hanstva nakanune otkochevki vo vtoroj polovine XVIII v. [The socio-economic status of the Kalmyk Khanate on the eve of the migration in the second half of the XVIII century] / M.M. Zagorul'ko (Ed.), Ekonomicheskaya istoriya Rossii: problemy, poiski, resheniya. - Volgograd: Volgogradskij gosudarstvennyj universitet. - 2003. S. 183-190. (In Russian)

39. Cyuryumov A.V. K voprosu ob otkochevke kalmykov v Kitaj: social'noehkonomicheskie prichiny [in the issue of the migration of Kalmyks to China: socioeconomic reasons]. Ekonomicheskie problemy $\mathrm{v}$ istorii Rossii i puti ih resheniya. SPb. - 2003. - S. 10-11. (In Russian)

40. Chernyshev I.A. O perekochevke volzhskih kalmykov v Dzhungariyu v 1771 g. [On the migration of Volga Kalmyks to Dzungaria in 1771]. In A.I. Kobzev (Ed.), XV nauchnaya konferenciya «Obshchestvo i gosudarstvo v Kitae». Tezisy dokladov. Ch. II. - M.: Institut vostokovedeniya RAN, 1984. - S. 152-161. (In Russian)

41. Chimitdorzhiev Sh.B. O perekochevkah ojratov (kalmykov) v XVIIXVIII vv. «Torgutskij pobeg» $1771 \mathrm{~g}$. [On the migrations of Oirats (Kalmyks) in the XVII-XVIII centuries. "Torgutsky Escape" 1771]. In Sh. B. Chimitdorzhiev (Ed.), Issledovaniya po istorii i kul'ture Mongolii. - Novosibirsk: Nauka: Sib. otd-nie, 1989. - S. 62-66. (In Russian).

Поступила в редакцию 10 ноября 2018 г. 
UDC 920.253

DOI: $10.21779 / 2542-0313-2018-33-4-6-18$

\section{The role of Kalmyks in Russian-Chinese relations throughout the XVIIIth century: historiography}

\section{O.N. Boldyreva}

Kalmyk State University named after B.B. Gorodovikov; Russia, the Republic of Kalmykia,358000,Elista,Pushkin st., 11; Olya.boldyreva2013@yandex.ru

The relevance of this article is determined by the need to further study the role of the Kalmyk Khanate in Russia's eastern policy, with the focus on the eighteenth century, when the khanate was at its peak. This is important not only for the history of the Kalmyk people proper, but also for studying and highlighting the participation of the peoples that were a part of Russia in its foreign policy activities at this or that period.

When analyzing the role of the Kalmyk Khanate in the XVIII century, one can compare its relations with Russia and the Central Asian region as a whole, and with separate countries, for example, with China. It is known that the steppe peoples, including the Kalmyks, played an important role in the history of the Central Asian region. In this regard, the study of the relationship of the Kalmyk Khanate with Qing China in the 18th century seems to be very important. Firstly, a study of the history of relations between the Kalmyk Khanate and the country makes it possible to affirm the autonomous status of the Khanate, in spite of Russia's protectorate. This implies that Kalmykia could have its own diplomatic relations with the countries of Central Asia. Secondly, when analyzing the role and place of the Kalmyk khanate in the eastern policy of the Russian state, it is necessary to take into account Russia's attitude to China during this period, as well as the problems of the inter-relations of the above-mentioned countries and with the Russian Empire. The analysis of the historiography in the problem raised confirms the topicality of the problem emphasizing the role of the Kalmyk Khanate in the eastern policy of Russia and gives the right to assert that the Kalmyk Khanate played an important role in politics, despite Russia's protectorate.

Keywords: Kalmyk Khanate, Qing China, historiography, relations, periods, Russia, Kalmyks' migration to China.

Received 10 November, 2018 